\title{
Dry matter and crude protein digestibility of locally prepared concentrates by calves at different ages*
}

\author{
H.L.N. Lyimo ${ }^{1,3}$, G.H. Laswai ${ }^{1}$, L.A. Mtenga ${ }^{1}$, A.E. Kimambo ${ }^{1}$, \\ T. Hvelplund ${ }^{2}$ and M.R. Weisbjerg ${ }^{2}$
}

\author{
${ }^{1}$ Sokoine University of Agriculture \\ P.O. Box 3004, Morogoro, Tanzania \\ ${ }^{2}$ Danish Institute of Agricultural Sciences, Research Centre Foulum \\ P. O. Box 50, DK-8830, Tjele, Denmark
}

\begin{abstract}
Thirty crossbred calves were randomly allocated to six treatments in a 3 diet $\times 2$ weaning age factorial arrangement to study the effects of weaning age and type of locally prepared pre-weaning concentrate on dry matter (DM) and crude protein (CP) digestibility at the age of 1,2,3 and 4 months. Diets were concentrate A, whole milk and hay (T1), concentrate B, whole milk and hay (T2) and whole milk and hay (T3), respectively. Weaning was either at 9 or 12 weeks age. The concentrates were isoenegetic and iso-proteinous (12.9 MJ ME/ $/ \mathrm{kg} \mathrm{DM}$ and $180 \mathrm{~g} \mathrm{CP} / \mathrm{kg} \mathrm{DM}$ ) but differed in the ingredients used to prepare them and were fed liberally until the consumption reached $1 \mathrm{~kg}$. Milk was offered at the rate of 41 a day and reduced gradually to reach 21 at weaning. Hay and clean water were offered liberally from two weeks of age. Weaning at 9 or 12 weeks had small but insignificant effects on all of the studied parameters. Differences in dry matter digestibility (DMD) started at the second month of age, whereby T3 had significantly $(\mathrm{P}<0.01)$ lower DMD $(73 \%)$ compared to T1 $(78 \%)$ and T2 $(76 \%)$. Digestible crude protein (DCP) was different only at the $2^{\text {nd }}$ month whereby $\mathrm{T} 3$ had higher $\mathrm{DCP}(\mathrm{P}<0.05)(85 \%)$ compared to T1 and T2 (71 and 69\%). There was no significant difference between the supplemented groups in DMD or DCP. It was concluded that, concentrates prepared from local available feed resources could be effectively used and digested by calves from the second month of age.
\end{abstract}

KEY WORDS: calf, concentrate, digestibility

\section{INTRODUCTION}

At birth the calf stomach functions similar to that of monogastric in the sense that only the abomasum is functional while the other parts are underdeveloped in

\footnotetext{
* Supported by DANIDA through ENRECA ASLIP Project

${ }^{3}$ Corresponding author: e-mail: hlnlyimo@yahoo.com
} 
both size and function (Roy, 1980). Due to this the young calf concentrates should preferably be made of milk and milk derivatives or readily digestible materials (NRC, 2001; Khan et al., 2002). On the other hand introduction of solid feeds to calves early facilitate rumen development (Roy, 1980). Feed meant for the calf should be palatable, with high digestibility and sufficient nutrient concentration to make it a possible substitute or supplement to milk.

Little has been done in developing countries including Tanzania in search for proper formulations to be used as calf concentrates in order to save milk that is needed for human consumption. Imported calf concentrates are not available and if available would be expensive for the smallholder farmers to adopt. Feeds formulated from locally available feed resources would possibly make cheaper calf concentrate. This study was conducted in order to evaluate the digestibility of two calf concentrates formulated from locally available feed material at $1,2,3$ and 4 months of age.

\section{MATERIAL AND METHODS}

The experiment was conducted at Sokoine University of Agriculture (SUA), Morogoro (Tanzania). Thirty crossbred male calves (Bos taurus $x$ Bos indicus) were purchased at the age of 4 to 5 days and randomly arranged in a $3 \times 2$ factorial design with three d-iets (TI, T2 and T3) and weaned at either 9 or 12 weeks. The three dietary treatments included concentrate A, whole milk and hay (T1), concentrate B, whole milk and hay (T2) and whole milk and hay (T3). The two concentrates (A and B) were formulated using different feed materials available within Morogoro Region to meet the recommended level of energy, protein, crude fibre, calcium and phosphorus in calf concentrates (NRC, 2001). Concentrate A was composed of hominy feed (59\%), Ipomoea aquatica meal (14\%), sunflower seed cake (14\%), fish meal (7\%), molasses (5\%), bone meal $(0.5 \%)$, and common salt $(0.5 \%)$. Concentrate B was composed of hominy feed (69), cassava root meal $(5 \%)$, simsim meal (5\%), sunflower seed cake (14\%), fish meal (6\%), bone meal $(0.5 \%)$, and common salt $(0.5 \%)$. Calves were housed in individual pens and milk was fed at 08.00 and $13.00 \mathrm{~h}$ in equal share in a bucket and reduced gradually from 41 at birth to 21 at weaning at week 9 or 12 . Concentrate was offered liberally after milk feeding starting from the second week and increased gradually to a maximum of $1 \mathrm{~kg}$. Hay was provided ad libitum in two portions at 08.00 and $13.00 \mathrm{~h}$ from the second week of age to all groups. Clean fresh water was also provided daily. Amount offered and refusal for both hay and concentrates were measured daily to calculate feed intake. Post weaning, calves continued with their respective diet up to the $4^{\text {th }}$ month. After every 30 days, plastic bags were harnessed to the calves to enable total collection of faeces for four consecutive periods. Faeces produced by each animal was collected and weighed daily, and samples from individual 
animal were taken for subsequent analysis. Proximate components of feeds and faecal samples were analysed according to the procedures of AOAC (1990). Nitrogen in the faeces was analysed from fresh samples. Nutrient digestibility from each treatment was calculated as the difference between total nutrients in the diet offered and that in the faeces. Treatment effects on nutrient digestibility by the calves after every 30 days were analysed using the GLM procedure of SAS (2000).

\section{RESULTS AND DISCUSSION}

Energy and protein content of the diet was within recommendations for calf concentrate 12-13 MJ ME/kg DM and 160-200 g CP/kg DM, respectively (NRC, 2001). Concentrate A had higher crude fibre (CF) content (10.9\%) compared to concentrate $\mathrm{B}(7.6 \%)$, a value that was slightly higher than the recommended level of $<10 \% \mathrm{CF}$ in calf concentrates (NRC, 2001). This was attributed by inclusion of Ipomoea meal, which contains high CF that might have contributed to reduce digestibility at the early age because of the immature rumen.

Weaning system had no significant $(\mathrm{P}<0.05)$ effect on nutrient digestibility by the calves at any age. There was no significance difference $(\mathrm{P}>0.05)$ in digestibility between the dietary treatments at the $1^{\text {st }}$ month of age (Table 1 ) and the values were higher than for the subsequent months. At this age, a large proportion of the diet $(>80 \%)$ was composed of milk, which is reported to be highly digestible (Raven, 1972). The values for DMD and DCP obtained at this age were higher than those reported by Mandibaya et al. (1999) for calves fed locally prepared calf concentrates at 35 days of age (59-67\% DMD and 45-67\% DCP). The difference is probably due to type of diet used. Mandibaya et al. (1999) used diets of lower energy and protein content (9-10 MJ ME/kg DM and 10-15\% CP) compared to those used in the present study.

Table 1. Effects of the treatments on DM and CP digestibility

\begin{tabular}{|c|c|c|c|c|c|c|c|c|}
\hline \multirow{3}{*}{ Treatment } & & & \multicolumn{4}{|c|}{ Digestibility, \% } & & \\
\hline & \multicolumn{2}{|c|}{1 month } & \multicolumn{2}{|c|}{2 months } & \multicolumn{2}{|c|}{3 months } & \multicolumn{2}{|c|}{4 months } \\
\hline & DM & $\mathrm{CP}$ & DM & $\mathrm{CP}$ & DM & $\mathrm{CP}$ & DM & $\mathrm{CP}$ \\
\hline $\mathrm{T} 1$ & 84.25 & 81.95 & $77.52^{\mathrm{a}}$ & $70.68^{b}$ & $71.26^{\mathrm{a}}$ & 62.88 & $74.90^{\mathrm{a}}$ & 58.79 \\
\hline $\mathrm{T} 2$ & 86.55 & 87.10 & $75.86^{\mathrm{a}}$ & $69.05^{b}$ & $70.59^{\mathrm{a}}$ & 60.97 & $70.39^{a}$ & 60.07 \\
\hline $\mathrm{T} 3$ & 85.39 & 87.39 & $72.95^{\mathrm{b}}$ & $85.00^{\mathrm{a}}$ & $63.57^{\mathrm{b}}$ & 64.56 & $55.30^{\mathrm{b}}$ & 66.81 \\
\hline SE & 2.19 & 2.71 & 1.06 & 1.93 & 2.18 & 2.98 & 3.01 & 3.53 \\
\hline Significance & NS & NS & $* *$ & $* * *$ & $* *$ & NS & $* * *$ & NS \\
\hline
\end{tabular}

significance level $* \mathrm{P}<0.05, * * \mathrm{P}<0.01, * * * \mathrm{P}<0.001$

means with same superscript letters within column for each effect are not significantly different 
There was a general decrease in digestibility of DM, and CP in the diets from the first month to the second month of age (Table 1). This is due to the reduction of the proportion of milk in the diets followed by an increased consumption of hay and concentrates resulting in a reduction of easily digestible components in the total diets.

From the second month of age, calves on $\mathrm{T} 1$ and $\mathrm{T} 2$ had significantly $(\mathrm{P}<0.05)$ higher DMD than calves on T3 this is because energy and protein supplied in T3 without concentrate and milk being withdrawn was rather low to support high fermentation in the functional rumen. A lower DMD for T3 compared with T1 and T2 was also obvious for the $3^{\text {rd }}$ and $4^{\text {th }}$ months. DCP was not affected by diet for the $3^{\text {rd }}$ and $4^{\text {th }}$ month where the treatment groups only showed minor variations. This also indicates that full rumen maturity and optimal ability to digest the solid diet was reached within this period. The age to attain full functional rumen differs considerably from 4-9 weeks, and is related to a number of factors like breed, age, diet and feeding strategy (Khan et al., 2002).

\section{CONCLUSIONS}

Calf concentrates from locally available feed resources in Morogoro could be used. Inclusion of concentrate in the diets enhanced digestibility from the second month of age when milk is withdrawn compared to calves fed without concentrate and only supplemented with hay.

\section{REFERENCES}

AOAC, 1990. Official Methods of Analysis, Association of Official Analytical Chemist. $15^{\text {th }}$ Edition. Vol. 11. Arlington, VA

Beaucheman K.A., Lachance B., Laurent G.S., 1990. Effect of concentrate diets on performance and carcass characteristic of veal calves. J. Anim. Sci. 68, 35-44

Khan A.G., Alliya Azim, Mirza I.H., 2002. Response of feeding amino acid supplemented cotton seed meal on growth performance, digestibility of early weaned cow calves. Asian-Austr. J. Anim. Sci. 15, 184-192

Mandibaya W., Mutisi C., Hamundikuwanda H., Titterton M., 1999. Nutritive value intake digestibility and nitrogen balance of farm grown and prepared sunflower based dairy calf meals. Trop. Anim. Health Prod. 31, 321-333

National Research Council (NRC), 2001. Nutrient Requiremet for Dairy Cattle. 7th revised Edition. National Academy Press, Washington, DC

Ranjham S.C., 1981. Animal Nutrition in the Tropics. $2^{\text {nd }}$ Edition. VPH Ltd., pp. 480

Raven A.M., 1972. Nutritional effects of including different levels and sources of protein in milk replacers for calves. J. Sci. Food Agr. 23, 517-523

Roy J.H.B., 1980. The Calf. $4^{\text {th }}$ Edition. Butterworths Inc., London, pp. 256

SAS, 2000. Statistical Analysis System. Users Guide. Statistical Analysis Institute, Inc. Cary, NC 